\title{
Insecticide usage Pattern against Helicoverpa armigera (Hubner) in Karnataka State, India
}

\author{
S.B. Honnakerappa* and S.S. Udikeri \\ Department of Agricultural Entomology, University of Agricultural Sciences, \\ Dharwad - 580 005, Karnataka, India \\ *Corresponding author
}

\section{A B S T R A C T}

\begin{tabular}{|l|}
\hline Ke y w o r d s \\
Insecticides, \\
Helicoverpa \\
armigera, Host, \\
Karnataka
\end{tabular}

10 August 2018

\begin{abstract}
An interactive survey was conducted during 2016-17 to document insecticide usage pattern adopted by the farmers of Karnataka state to manage polyphagous pest Helicoverpa armigera in different host crops growing areas. Among the different group of insecticides the most popular amongst the farmers were emamectin benzoate 5 SG $(39.44 \%)$, rynaxypyr $18.5 \mathrm{SC}(27.22 \%)$ and profenophos $50 \mathrm{EC}(23.89 \%)$. The dominant host crops for $H$. armigera different in the state were cotton, pigeonpea in Raichur and Kalaburgi, chickpea (Gadag), chilli (Haveri) and tomato (Kolar). Manually operated knapsac sprayer was commonly used in all localities except in Raichur and Kalaburgi where power operated sprayers were used. The refugia usage in $B t$ cotton was about $40 \%$ farmers only.
\end{abstract}

\section{Introduction}

Helicoverpa armigera Hubner (Noctuidae: Lepidoptera) is a widely distributed insect pest in Europe, Africa, Asia and South Pacific regions. The currently noticed global distribution of $H$. armigera suggests that the pest may be most closely associated with deserts and xeric shrub lands; Mediterranean scrub; temperate broadleaf and mixed forests; tropical and subtropical grasslands, savannas, and shrub lands; and tropical and subtropical moist broadleaf forest (Wasihun, 2016). It has a wide host range of over 360 plant species that includes most crop hosts are tomato, cotton, pigeonpea, chickpea, sorghum and cowpea and other hosts dianthus, rosa, pelargonium, chrysanthemum, groundnut, okra, peas, field beans, soybeans, lucerne, Phaseolus spp, tobacco, potatoes, maize, flax, a number of fruits (Prunus, Citrus), forest trees and a range of vegetable crops (Multani and Sohi, 2002; CAB, 2006).

$H$. armigera solely cause losses up to Rs. 10,000 million in crops like cotton, pigeonpea, chickpea, groundnut, sorghum, pearl millet, tomato, and other crops of economic importance (Raheja, 1997). In chickpea and pigeonpea $H$. zea caused an estimated loss of \$ 927 million in worldwide apart from \$ 5.0 billion in different crops as reported by 
Sharma (2001) and annual loss of over $\$ 350$ million in pigeonpea. Yield loss in cotton was reported in Tamil Nadu and Karnataka to the range of 35-38\% and insecticides worth of 28,800 billion rupees were used annually on all crops in India of which $50 \%$ was used on cotton alone (Rai et al., 2009). However, with the extensive use of chemicals a widespread resistance to insecticides has been acquired by $H$. armigera in India. It is possessing by far the most reported cases of insecticide resistance worldwide with evolved resistance against pyrethroids $(50-100 \%$ metabolic resistance and $<5.0 \%$ target site), organophosphates (low - moderate 1-10\%), carbamates (moderate - high 30-50\%), organochlorines and recently against the macrocyclic lactone spinosad (very low <2\%) and Bacillus thuringiensis derived toxins (low $<5 \%$ ) oxadiazines (low, but increasing 5-12\%) diamides (very low <1\%), whereas zero level of resistance to avermectins, nuclear polyhedrosis virus and paraffinic spray oils in Australia as reported by Paul et al., (2018). Earlier reports indicated that cypermethrin and fenvalerate effectively reduced $H$. armigera population and damage. Due to continuous use of pesticides against this pest resulted in the development of resistance was evidenced (Jadhav and Armes, 1996) by very high level of resistance to synthetic pyrethroids, which occupied 50-70 per cent of the insecticides sprayed over the cotton in India. Thus ineffectiveness of insecticide predominantly has arisen from highly pesticide prone areas where intensive agriculture is in vague. Since then there is lot of change in insecticide usage pattern by growers to contain this pest, but, still it remains as dominant insect pest in India. It gives a scope to relate the degree of development of resistance in the population from different geographical areas vis-à-vis the diversity and/or intensity of pesticide usage by farmers. Over $>15$ years transgenic Bt cotton hybrids are cultivated in Karnataka which is likely to influence $H$. armigrea susceptibility in other crops also. Insecticide usage diversity, sprayer types and refugia adoption across the Karnataka have been reported in this study to know the status of resistance management of $H$. armigera presently.

\section{Materials and Methods}

\section{Survey area}

The survey was carried out during 2016-17 in different locations of Karnataka viz., Dharwad, Vijayapur, Belagavi, Gadag, Haveri, Raichur, Kalaburgi, Shivamogga and Kolar encompassing all agro climatic zone of the state where $H$. armigera host crops are regularly grown.

\section{Interview and questionnaire}

The interview with farmers was done to know about the extent of exposure to different types of pesticides, major host crops (considered by more than $50 \%$ area covered with particular crops in each farmers field), frequency of insecticide applications and other pest management practice for $H$. armigera including refugia in $\mathrm{Bt}$ cottons. In each district 20 farmers having better knowledge about pest management practices prevailing amongst them were consulted for this survey. The data collection was on a questionnaire based. The data collected was entered in the MS-Excel master worksheet, classified and used for further statistical analysis.

\section{Results and Discussion}

From the survey variation in dominance of host crops of $H$. armigera in different locations of Karnataka was evident (Table 1) like tomato in Kolar, chilli in Haveri, maize in Shivamogga, chickpea in Gadaga, cotton in Belagavi, Dharwad, pigeon pea in Raichur and Kalaburgi. In these areas where more than fifty percent holding of individual growers 
was covered by these crops. Thus based on crop acclimatization and environmental conditions the cropping pattern has a definite impact on management practices.

The average number of insecticides application by the farmers in order to conquer the $H$. armigera predicament varied on a average from 1.0 to 3.7 rounds of sprays. Maximum numbers of 3.7 sprays was recorded from the Raichur followed by 3.3 sprays from Kalaburgi. Whereas, lowest number of spray was recorded from Shivamogga (1.0 spray) followed by Belagavi (1.6 sprays) and Gadag (2 sprays) among different locations of Karnataka (Table 2). Similarly Fakruddin et al., (2004) observed more spray frequencies in Raichur against $H$. armigera itself. Thus Raichur and Kalaburgi have remained as high insecticide usage areas of Karnataka where pigeonpea, chickpea and irrigated cottons are predominantly grown.

The usage of different selected insecticides by the growers to combat $H$. armigera in different locations varied from 0 to $60 \%$ as depicted in Figure 1. Among the different insecticides the highest usage of rynaxypyr $(60 \%)$ was reported in Kolara (against tomatoes) which was followed by 50 per cent in botanicals as well as emamectin benzoate. Further, among the selected insecticides which were used by farmer the usage varied from 1.67 to $23.89 \%$.

The highest percent of farmers used emamectin benzoate $(39.44 \%)$ followed by rynaxypyr $(27.22 \%)$ and least usage of insecticides were bioagents, pyrethroids, carbamates and biorationales (Fig. 2). Thus the present study revealed reliance on newer group of insecticides much along with some conventional insecticides (OP groups) which could be due to experienced ineffectiveness of earlier used conventional insecticides.
Type of sprayer/nozzles and spray volume also has lot of influence on efficacy of insecticides and could be a cause for development of resistance. In the present study the spray equipment usage varied much across the regions. The manual operated knapsack sprayer was most common (Table 3) and about 15 to $80 \%$ farmers showed dependency on it except Raichur and Kalaburgi farmers. Power sprayer users ranged from 5 to $65 \%$ which was common in Raichur, Kalaburgi and Vijayapur districts for its reachability to high canopy of pigeonpea crop predominantly grown in these districts. Battery operated knapsack sprayer usage ranged from 15 to $25 \%$ mostly dominated in Raichur and Kalaburgi again. The spray equipment dependency is always related to canopy coverage, availability water and labour. However the dosage management is important rather than sprayers in pest management. The present study could not notice striking pitfall in spray equipment related issues. Growing non $\mathrm{Bt}$ cotton as structured refugia has been recommended as IRM practice in India. Even after 15 years of introduction of $B t$ cotton in India refugia adoption could not go beyond $40 \%$ (Fig. 3) as noticed in Dharwad district. The farmers have reasons like; loss in area for Bt crop due to refugee seeds, more pest infestation on refugia, poor knowledge about refuge requirement etc for non compliance of refugia. However, this could be potential threat for sustainability of Bt technology as evidenced in $B t$ cotton impact evaluation (Anonymous, 2014) studies.

Thus, the present investigation reveals a considerable deal of insecticide usage against $H$. armeigera in its host crops with variation in patterns. However, in cotton the usage of insecticide for $H$. armigera management has been dwindled significantly due to effect of $\mathrm{Bt}$ technology. 
Table.1 Dominance of Helicoverpa armigera host crops Karnataka State

\begin{tabular}{|l|l|l|}
\hline District & Dominant crops & Other host crops \\
\hline Haveri & Chilli, Cotton, Maize & Sunflower, Tomato, Bhendi \\
\hline Vijayapur & Cotton, Pigeonpea & Chickpea, Sunflower, Safflower \\
\hline Dharwad & Cotton, Chickpea, & Chilli, Sunflower, Maize, Safflower, Bhendi \\
\hline Belagavi & Cotton, Chilli, Sorghum & Chickpea, Sunflower, Safflower \\
\hline Shivamogga & Maize, Chilli & Sunflower \\
\hline Kolar & Tomato & Maize, Bhendi \\
\hline Raichur & Pigeonpea, Cotton & Chickpea, Sunflower \\
\hline Kalaburgi & Pigeonpea, Cotton, Chickpea & Maize, Bhendi \\
\hline Gadag & Chickpea, Cotton & Chilli, Sunflower, Maize, Safflower, Bhendi \\
\hline
\end{tabular}

Fig.1 Insecticide usage pattern against $H$. armigera in different locations of Karnataka

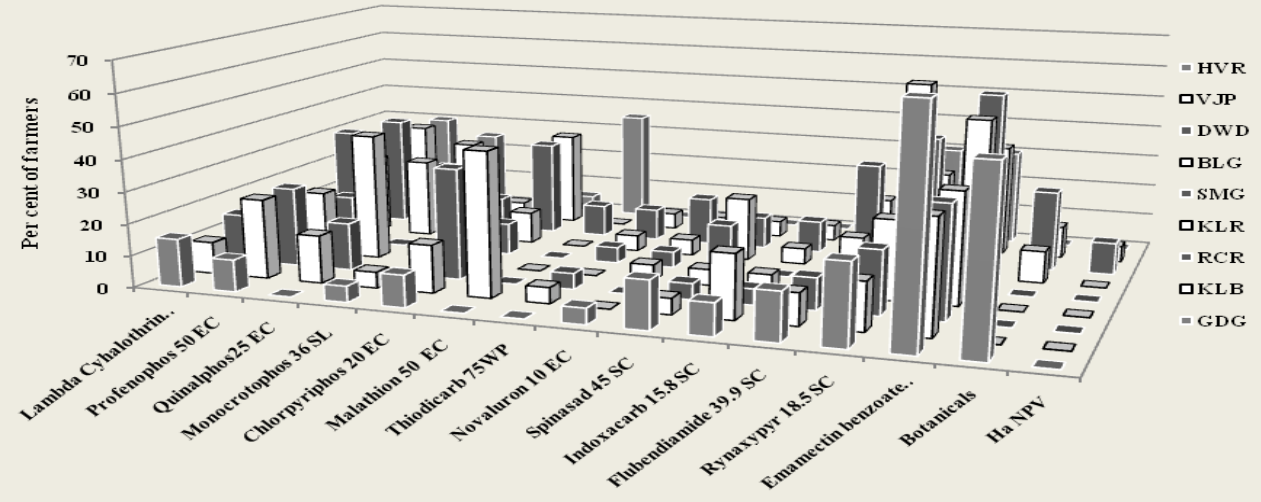

Fig.2 Percent of Farmers used different insecticides in Karnataka during 2016-17

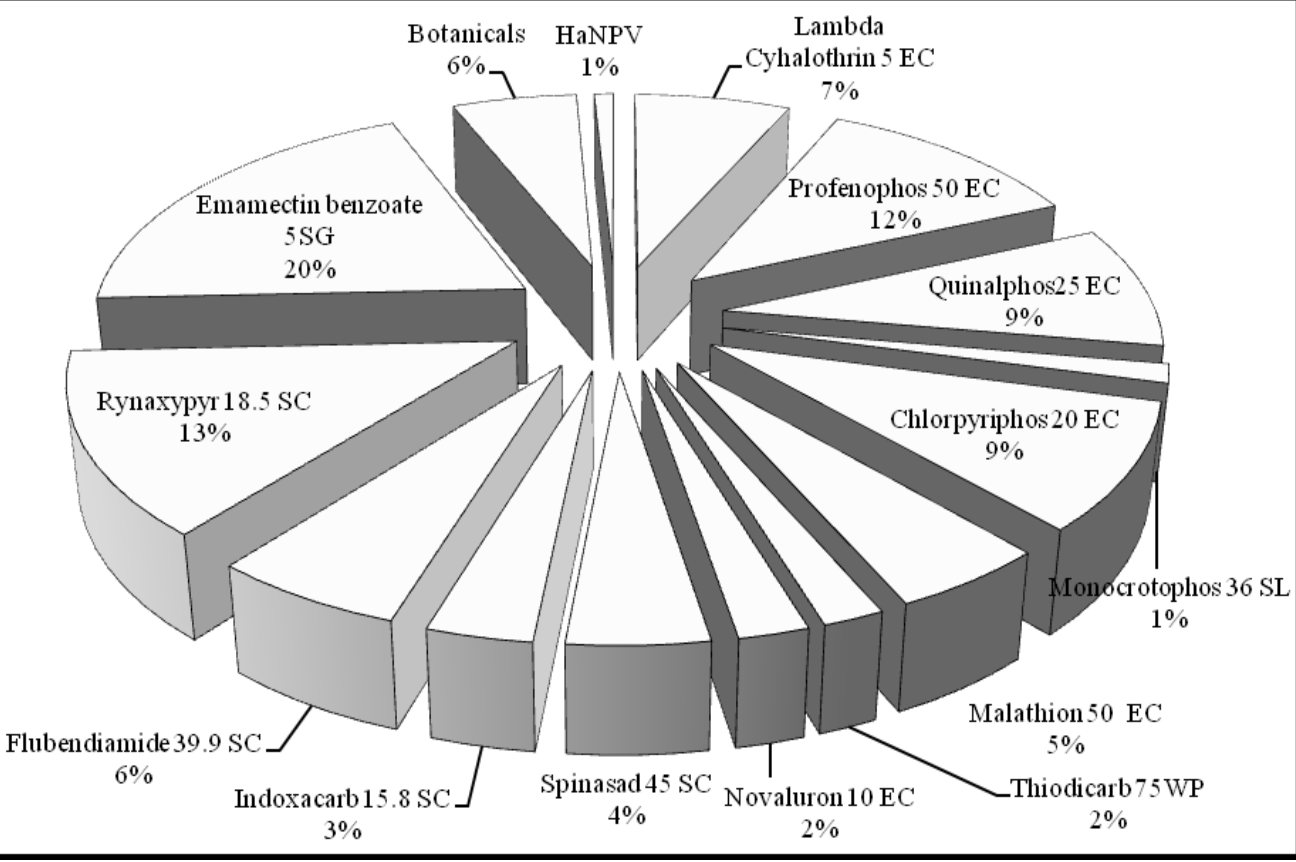


Table.2 Insecticide usage pattern against Helicoverpa armigera in different locations of Karnataka

\begin{tabular}{|c|c|c|c|c|c|c|c|c|c|c|c|}
\hline \multirow{2}{*}{$\begin{array}{l}\text { Insecticide } \\
\text { group }\end{array}$} & \multirow[t]{2}{*}{ Insecticide } & \multicolumn{9}{|c|}{ Number of farmers* $(\%)$} & \multirow[t]{2}{*}{ Mean $(\%)$} \\
\hline & & HVR & VJP & DWD & BLG & SMG & KLR & RCR & KLB & GDG & \\
\hline Pyrethroids & $\begin{array}{l}\text { Lambda Cyhalothrin } 5 \\
\text { EC }\end{array}$ & 15 & 10 & 15 & 10 & 5 & 10 & 30 & 20 & 10 & 13.89 \\
\hline \multirow{5}{*}{$\begin{array}{l}\text { Organo } \\
\text { phosphates }\end{array}$} & Profenophos 50 EC & 10 & 25 & 25 & 20 & 15 & 25 & 35 & 30 & 30 & 23.89 \\
\hline & Quinalphos25 EC & 00 & 15 & 15 & 40 & 0 & 25 & 20 & 25 & 25 & 18.33 \\
\hline & Monocrotophos $36 \mathrm{SL}$ & 05 & 5 & 0 & 0 & 0 & 0 & 10 & 5 & 0 & 2.78 \\
\hline & Chlorpyriphos $20 \mathrm{EC}$ & 10 & 15 & 35 & 25 & 10 & 10 & 30 & 30 & 5 & 18.89 \\
\hline & Malathion 50 EC & 00 & 45 & 0 & 0 & 0 & 0 & 10 & 0 & 35 & 10.00 \\
\hline Carbamates & Thiodicarb 75WP & 00 & 5 & 5 & 0 & 5 & 5 & 10 & 5 & 0 & 3.89 \\
\hline IGR's & Novaluron $10 \mathrm{EC}$ & 5 & 0 & 0 & 5 & 5 & 5 & 15 & 5 & 0 & 4.44 \\
\hline Spinosyns & Spinasad 45 SC & 15 & 5 & 5 & 5 & 15 & 20 & 10 & 5 & 0 & 8.89 \\
\hline Oxadiazines & Indoxacarb $15.8 \mathrm{SC}$ & 10 & 20 & 5 & 5 & 0 & 5 & 10 & 5 & 0 & 6.67 \\
\hline Benzenes & Flubendiamide $39.9 \mathrm{SC}$ & 15 & 10 & 10 & 5 & 5 & 10 & 30 & 15 & 10 & 12.22 \\
\hline \multirow[t]{2}{*}{ Diamides } & Rynaxypyr 18.5 SC & 25 & 15 & 20 & 25 & 5 & 60 & 40 & 25 & 30 & 27.22 \\
\hline & $\begin{array}{l}\text { Emamectin benzoate } \\
5 \mathrm{SG}\end{array}$ & 70 & 35 & 35 & 35 & 10 & 50 & 55 & 35 & 30 & 39.44 \\
\hline $\begin{array}{l}\text { Plant } \\
\text { product }\end{array}$ & Botanicals** & 55 & 00 & 00 & 0 & 0 & 10 & 25 & 10 & 0 & 11.11 \\
\hline Bioagent & $H a \mathrm{NPV}$ & 00 & 00 & 00 & 0 & 0 & 00 & 10 & 5 & 0 & 1.67 \\
\hline
\end{tabular}

HVR- Haveri, VJP- Vijayapur, DWD- Dharwad, BLG- Belagavi, SMG- Shivamoga, KLR- Kolar, RCR- Raichur, KLB- Kalburgi, GDG- Gadag $* \mathrm{~N}=20$

** Bioneem, Brahmastra, Pro-47 and other plant products 
Table.3 Insecticide usage diversity, sprayer types in different locations of Karnataka targeting Helicoverpa armigera

\begin{tabular}{|c|c|c|c|c|c|}
\hline \multirow[t]{2}{*}{ Locations } & \multirow[t]{2}{*}{ Crops } & \multirow{2}{*}{$\begin{array}{l}\text { Rounds of } \\
\text { insecticides } \\
\text { used (No.) }\end{array}$} & \multicolumn{3}{|c|}{ Type of sprayers used by farmer (\%) } \\
\hline & & & $\begin{array}{c}\text { Manual operated } \\
\text { (Knapsack) }\end{array}$ & $\begin{array}{c}\text { Power operated } \\
\text { sprayer }\end{array}$ & $\begin{array}{c}\text { Battery } \\
\text { operated } \\
\text { (Knapsack) }\end{array}$ \\
\hline Haveri & A & 5 & 80 & 05 & 15 \\
\hline Vijayapur & $C \& B$ & 6 & 40 & 50 & 10 \\
\hline Dharwad & A \& C & 6 & 80 & 05 & 15 \\
\hline Belagavi & $\mathrm{A} \& \mathrm{C}$ & 5 & 75 & 10 & 15 \\
\hline Shivamogga & A & 4 & 85 & 05 & 10 \\
\hline Kolar & $\mathrm{D}$ & 6 & 65 & 10 & 15 \\
\hline Raichur & $B \& C$ & 9 & 15 & 60 & 25 \\
\hline Kalaburgi & $B \& C$ & 7 & 15 & 65 & 20 \\
\hline Gadag & $\mathrm{C}$ & 6 & 75 & 10 & 15 \\
\hline
\end{tabular}

A- Chilli, B- Pigeonpea, C- Chickpea, D- Tomato; Sample size $(n)=20 /$ district

Fig.3 Refugia adoption by in major Bt cotton growing districts of Karnataka State

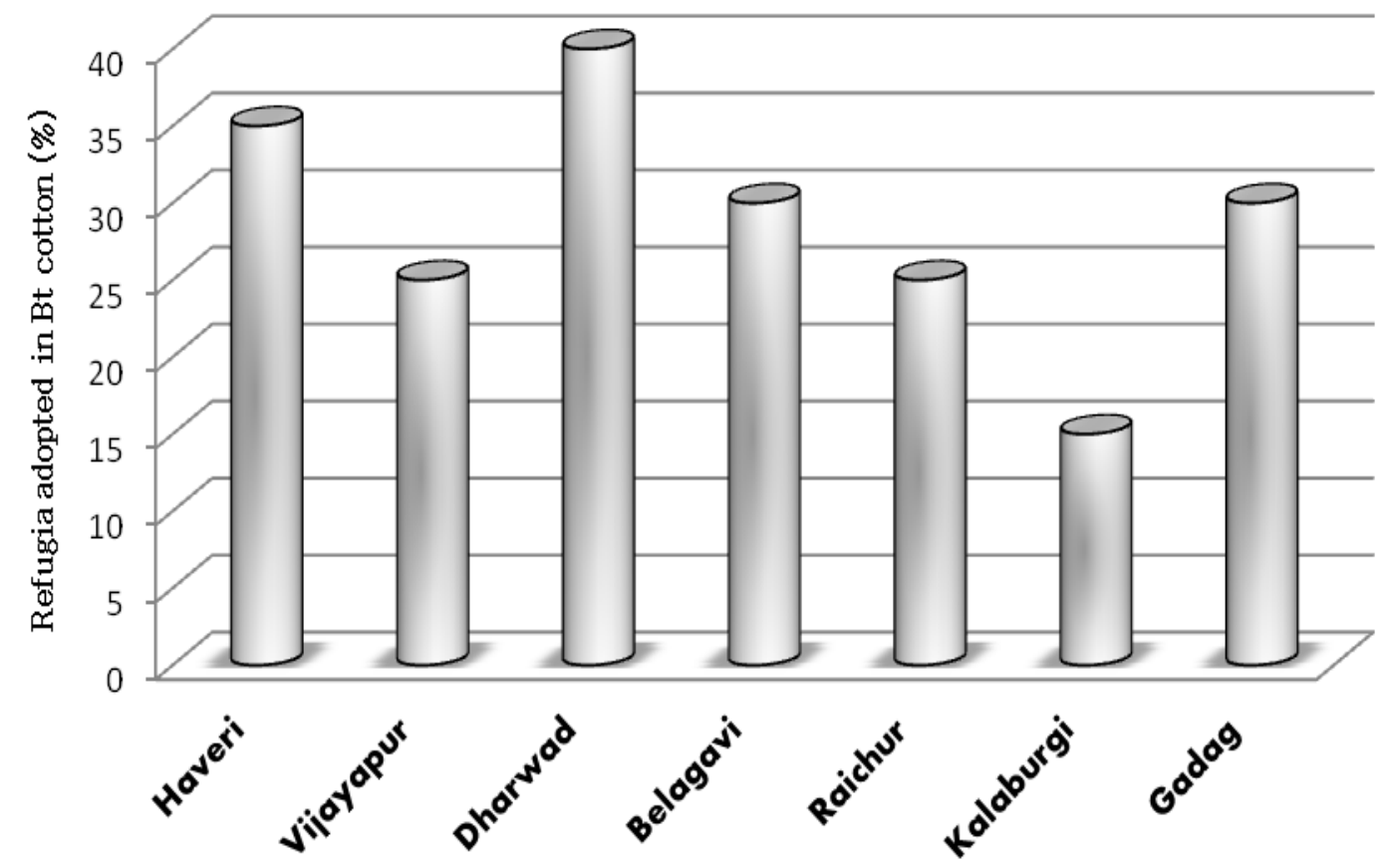


Farmers quite frequently rely on newer insecticide available in the market for successful management of the pest. It is good that presently farmers are depending much on new group of insecticides and doing away with conventional organophosphates and pyrethroids. Though such studies were not available for comparison with respect to $H$. armigerea as polyphagous single pest in different crops, the changes in insecticides usage patterns have been documented in cotton and vegetables (Silas et al., 2011), fruit crops (Lynn and Susan, 2003) and cereals (Heong et al., 2008) mentioning the resistance and change in insect pest scenario as root cause for the phenomenon. There appears in reduction over years in pesticides against dreaded pest $H$. armigera under the influence of $\mathrm{Bt}$ cotton too as in a multicropping system negative cross resistance operates reducing synthetic insecticide resistance. The studies on pesticide usage as in present case would guide the farmers also apart from generating information for pest management researchers and advisors. However. There should be more frequency in such studies across time and space for proper understanding of pest management issues spurting now and then.

\section{References}

Anonymous, 2014, Impact Evaluation \& Socio Economic Study of Bt Cotton, Final Report, Global Agrisystem Private Limited. pp. 48-49.

CAB, 2006, Crop Protection Compendium. CAB International, Wallingford, UK.

Fakrudin, B., Patil, B. V., Prasad, P.R.B. and Prakash, S. H., 2004, Insecticide usage patterns in South Indian cotton ecosystems to control cotton bollworm. Helicoverpa armigera. Resistant Pest Mgt. Newsltr., 12 (2): 35-38.

Heong, K. L., Ecakda, M. M and Mai, V., 2008, An analysis of insecticide use in rice: Case studies in Phillippines and Vietnam. Int. J. Pest Mgt., 40:173178.

Jadhav, D. R and Armes N. J., 1996, Comparative status of insecticide resistance in $H$. armigera species (Lepidoptera: Noctuidae) of south India. Bull. Ent. Res., 86: 525-531

Lynn E and Susan, B., 2003, Pattern of peticides use in California: The implications for strategies for selective of pesticide. Ann. Rev. Phytopathology, 41:351-375.

Multani, J. S. and Sohi, A. S., 2002, Helicoverpa armigera (Hubner) on carnation, Dianthus caryophyllus Linn. in Punjab. Insect Environ., 8: 82.

Paul Umina, Siobhan de Little, Lisa Kirkland., Elia Pirtle and James Maino., 2018, Managing insecticide resistance (Helicoverpa armigera, green peach aphid) and an update on Russian wheat aphid, GRDC Updates. https://grdc.com.au/resourcesand.../grdc-update-papers downloaded on $13 / 3 / 2018$

Raheja, A. K., 1997, IPM Research and Development in India: Progress and Priorities. In: Recent Advances in Indian Entomology (Ed. O.P. Lal). APC Publications Pvt. Ltd., New Delhi., pp.115-126.

Rai, M., Acharya, S. S., Virmani, S. M. and Aggrawal, P. K., 2009, State of India Agriculture. National Academy of Agricultural Sciences, New Delhi.

Sharma, H. C., 2001, Cotton bollworm/Legume pod borer, Helicoverpa armigera (Hubner) (Lepidoptera: Noctuidae) biology and management, Crop protection compendium: $\mathrm{CAB}$ International Wallingford, UK., pp. 72.

Silas, W. A, Ebeneza, O. O and Vincent, Y. E., 2011, Farmer perception on insects pest control and insecticide usage 
pattern in selected areas of Ghana. New York Sci. J., 4:23-29

Wasihun, Y. W., 2016, Biological control of chickpea pod borer, Helicoverpa armigera Hubner (Lepidoptera: Noctuidae) A global concern. World Scientific News, 45(2): 92-110. Yihua
Yang, Yapeng Li and Yidong Wu., 2013, Current status of insecticide resistance in Helicoverpa armigera after 15 years of Bt cotton planting in China. J. Econ. Entomol., 106(1):375381.

\section{How to cite this article:}

Honnakerappa, S.B. and Udikeri, S.S. 2018. Insecticide usage Pattern against Helicoverpa armigera (Hubner) in Karnataka State, India. Int.J.Curr.Microbiol.App.Sci. 7(08): 875-882. doi: https://doi.org/10.20546/ijcmas.2018.708.099 